Vol. 7, No. 1, 2021

UDC: 72.03

Yuriy Dzhyhil

\title{
ZAERA-POLO'S ARCHITECTURAL COMPASS AS A RESEARCH TOOL FOR MODERN CONCEPTS OF ARCHITECTURAL ENVIRONMENT DESIGN
}

\author{
PhD, Associate Professor \\ Department of Architecture Environment Design \\ Lviv Polytechnic National University, Lviv \\ e-mail: yuriydzhyhil@gmail.com \\ orcid: 0000-0002-4630-2501
}

Received: 15.12.2020 / Revised: 27.03.2021 / Accepted: 09.04.2021

(C) Dzhyhil Yu, 2021

https://doi.org/10.23939/as2021.01.017

Astract. The article examines the trends in modern architecture, outlined in the studies of architectural critic Alejandro Zaera-Polo and his team. The tool they've created was named "Interactive Map of Modern Architecture". Charles Jencks's 'Evolutionary Tree' (diagram of 20thcentury architecture) had a significant influence on this tool. The functionality of Zaera-Polo's map has been examined for five years by the author of this article while tutoring future architects at the Department of Architectural Environment Design at Lviv Polytechnic National University. These examinations allowed us to formulate a number of proposals to improve both - the structure of this map and the methodology of its creation.

Key words: modern architecture, interactive map, political compass.

\section{Problem statement}

The problem that is covered in this publication is related to changes in the concepts of development of modern architecture. This is primarily due to rapid changes in all areas of the globalized world. The generation of architects who in the 20th century and until recently had no alternative influence on the development of the profession was replaced by representatives of the young generation, who managed to make themselves known with their architectural works over the past less than two decades. These processes did not leave indifferent researchers of modern architecture. In particular, the Spanish architect and theorist Alejandro Zaera-Polo in 2015 together with his team, developed the so-called Map of Modern Architecture, which also received the name "political compass diagram of the architectural landscape".

There is also a generational change in Ukrainian architecture. Older architects who were educated in Soviet times are gradually being "replaced" by the generation of architects, who have already acquired a 
speciality in independent Ukraine. However, to this day, domestic construction and architecture are still based on an outdated regulatory and theoretical basis from the Soviet past. Ukraine's strategic desire for membership in the European Union requires adaptation of our norms and standards to European ones. Now the younger generation of architects who were born in independent Ukraine is entering an active professional life. A big role in their professional development will be played by how much they will be able to integrate into the processes that are taking place in the modern world architecture, in particular, processes that affect social progress and are reflected in foreign research. Not only the appearance but also the quality of the future environment of Ukrainian cities and settlements will depend on which of these architectural ideas our young people will be able to adopt and adapt to their projects. In this, I see the topicality of the research, and its purpose is to popularize the progressive foreign experience of architecture development on the basis of relevant modern research, including the Map of Modern Architecture (hereinafter referred to as the Map). The novelty of this study is a methodology for working with the Map, that is proposed, which will allow a more comprehensive assessment of each of the segments identified in it.

\section{Results and discussion}

The history of architecture of the second half of the 20th - beginning of the 21st century is described in the works of foreign [Jenks, 1985] and domestic (Circassian, Linda, 2010) researchers. When creating his Map, Alejandro Zaera-Polo was inspired by the diagram of the evolution of architecture in the 20th century by Charles A. Jenks (Fig. 1) (Jencks, 2000).

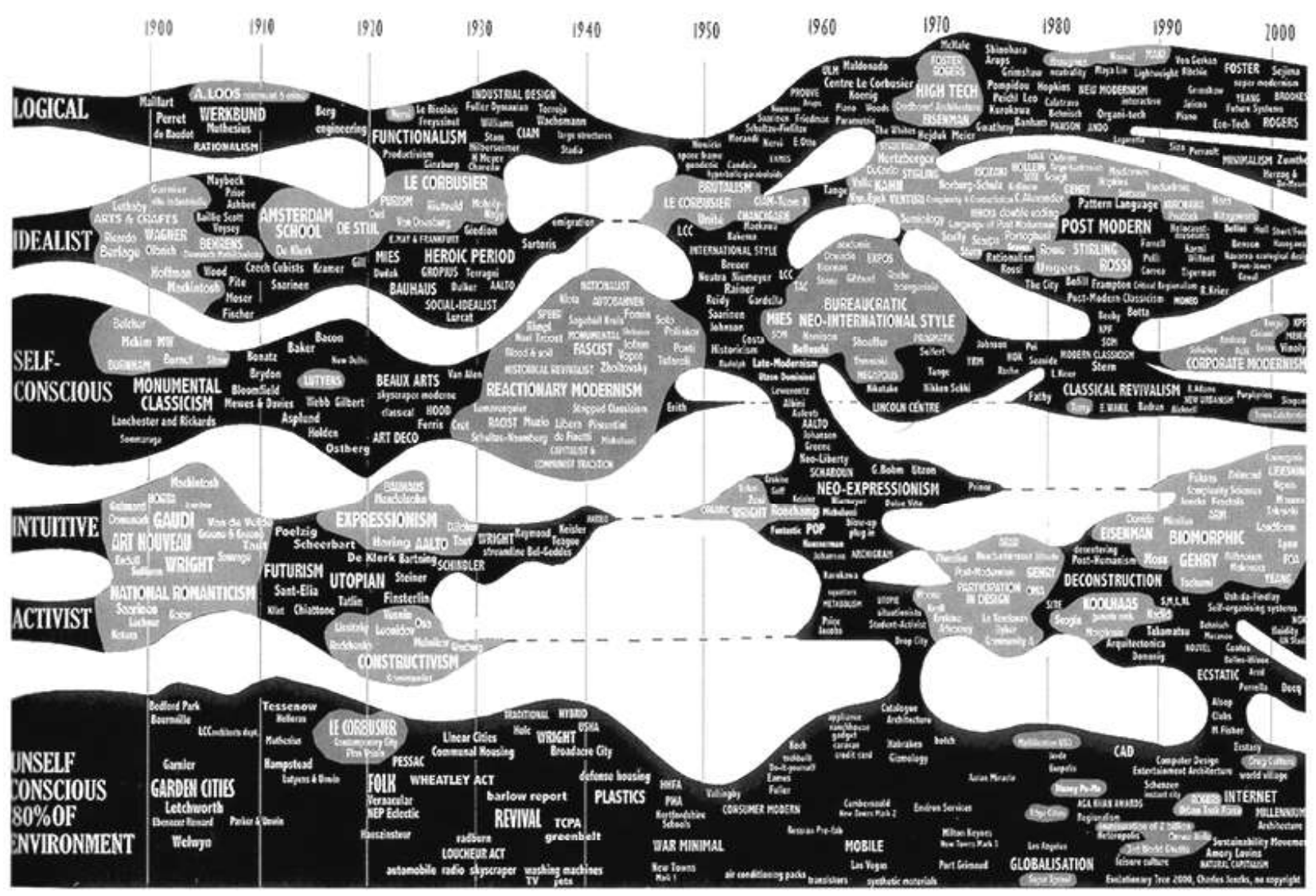

Fig. 1. The evolutionary tree or diagram of Charles Jenks' theory of evolution (Image (C) “July 2000: Jenks' theory of evolution, a review of 20th-century architecture”) [Jencks, 2000] 
The history of creating the Map is described in detail (Arch: speech .2017 a) and is not the subject of this study. However, I would like to emphasize some principled positions that clarify my interest in this Map.

Firstly, the methodology of creating the Map developed its features according to the diagram of Charles Jencks. In particular, in 2016, a team led by A. Zaera-Polo made the Map interactive. Alejandro Zaera-Polo, along with his colleague Guillermo Fernandez-Abascal, brought it to the Internet so that anyone could change the scheme at their discretion. (Alejandro Zaera-Polo, Guillermo Fernandez Abascal. 2016) Researchers expanded the possibilities of working with the Map, which allowed to:

- delete any bureau or move it to another zone;

- add new names to create an architectural map of your country/city/region;

- change direction boundaries;

- download the result;

- see where the participants identified themselves and find out their reaction to the result.

Secondly, starting 2017, I have included Map research in the program of the discipline "Modern Concepts of Architectural Environment Design", which is studied by 5th-year students specializing in "Architectural Environment Design". In particular, when they perform independent research in this discipline, I focused students' attention on studying the Map and preparing a presentation in one of the areas that are presented on it. Each student should defend their research in the process of presenting it and discussing it in practical classes on this course. At the same time, current trends should be linked to the processes that took place in the architecture of the second half of the 20 th and early 21 st centuries.

To reveal my suggestions for improving the Map, I have to reveal some of its well-known methodological and structural characteristics. To begin with, it all started with the appeal of the magazine "El Croquis" to write a short article about the state of the profession in our time. However, A. Zaera-Polo did not limit himself to the selected column of text and drew a whole diagram. In its seven sections, he placed 181 bureaus: this included only young teams that were formed in new, post-crisis times. According to the author, it ended along with the financial collapse of 2008. It was replaced by new concepts that the authors combined in one Map. They outlined the taxonomy of 21st-century architecture, trying to identify and classify various new forms of practice that gained popularity after the economic crisis. (Arch: speech. 2017 a)

In contrast to the linear evolutionary scheme of Charles Jenks (Fig. 1), A. Zaera-Polo built his scheme based on a circle divided into seven sectors by the content concepts of style directions, behind which clear theses were hidden: context, materials, form etc. (Fig. 2).

According to the plan of Alejandro Zaera-Polo, the categories defined by him were supposed to identify the main directions of development of modern architecture with seven generalized broad political positions. So he gave them the following names: Activists, Cosmopolitans, Material Fundamentalists, New Historians, Populists, Skeptics, Technological Utopians. These names are listed in alphabetical order.

The authors of the Map presented it in the form of a kind of compass dial, which made it easy to identify certain architectural firms with the presented division into seven concepts. Company names are grouped into specific sectors that have been highlighted in different colours. No clear boundaries were drawn between the seven groups represented. In some places, colour spots were superimposed on each other, which indicated the ambiguity of the author's classification.

The methodology of the map was simple: on the periphery of the circle are the brightest representatives of a particular direction, who are more orthodox in relation to others. Bureaus that were located closer to the centre borrowed more from other directions and had signs of a combination of styles (hybrid). At the time of creating the Map, there were almost no world-renowned architects among the 181 design firms represented in it. The authors of the Map deliberately gathered young teams that were formed in the new post-crisis times. 


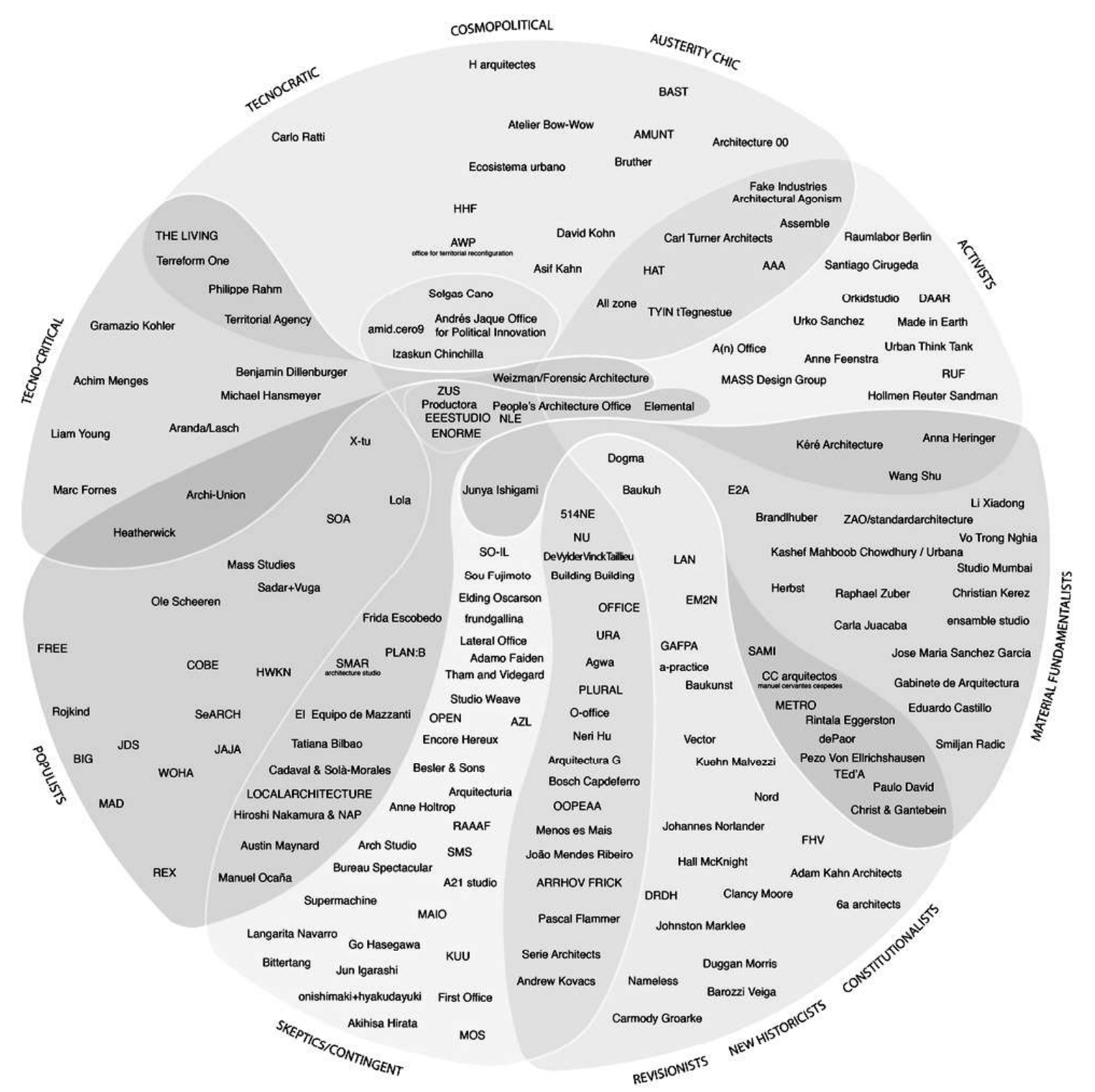

Fig. 2. Diagram of the political compass of an architectural landscape

(Image (C) Alejandro Zaera-Polo and Guillermo Fernandez Abascal) (Alejandro Zaera-Polo, Guillermo Fernandez Abascal, 2016)

Version 0.1 of the Map was published in the 187th issue of El Croquis magazine. The Map was also posted on the site globalarchitecturepoliticalcompass.com. The The publication of the Map caused lively discussions between its authors and architects, who were assigned to certain areas and who often did not agree with this. However, the map played a big role in popularizing the results of their work. After all, because of the names of companies, it became possible to access their websites, which made it easier to get information about companies, authors and their works. This made the search for this information in the modern architectural landscape easier, and also made it possible to make adjustments and change the configuration of coloured sectors over time. This was the interactive content of the map - everyone had the opportunity to become its co-author (Arch: speech. 2017 b).

\section{Results}

When getting acquainted with the object and subject of this research, I kept asking myself the question: "Why was the map called the political compass of the architectural landscape?" This name was adopted obviously 
for the reasons that architecture, as a reflection of modern society and, like any organized social movement, is based on fundamental political ideas. I think that we can find direct analogues for these seven main directions defined by the authors, which correspond to political trends with a formed ideology - from radical (right and left) to neoliberal (centrist). But this is a topic for a separate study.

The next thing that bothered me was about the new opportunities the map might give our students. Experience has shown that this practice allows you to track the following:

- independently conduct students' research on works of modern architecture, linking them with the architectural processes known to them at the turn of the 20th and 21st centuries;

- get information on each of the seven directions that are presented in the map, and participate in a joint discussion of presentations;

- compare multiple reports on the same topic, because I approve the tasks of research topics, evenly distributing them among students.

In the process of learning this interesting tool, I decided to supplement its structure. Without changing the cartographic basis set by Alejandro Zaera-Polo, I added four external factors that, in my opinion, make it possible to view the content of the map from different angles. Like the compass dial, in which the arrow orients to the main directions north-south and East-West, the Map circle is inscribed in a square with vertices that indicate the main factors influencing the conceptual design directions of the architectural environment: Aesthetic, Resource, Social, Technical. The names are given alphabetically, because, from the point of view of their impact on the architecture, they are equivalent and not separate (Fig. 3).

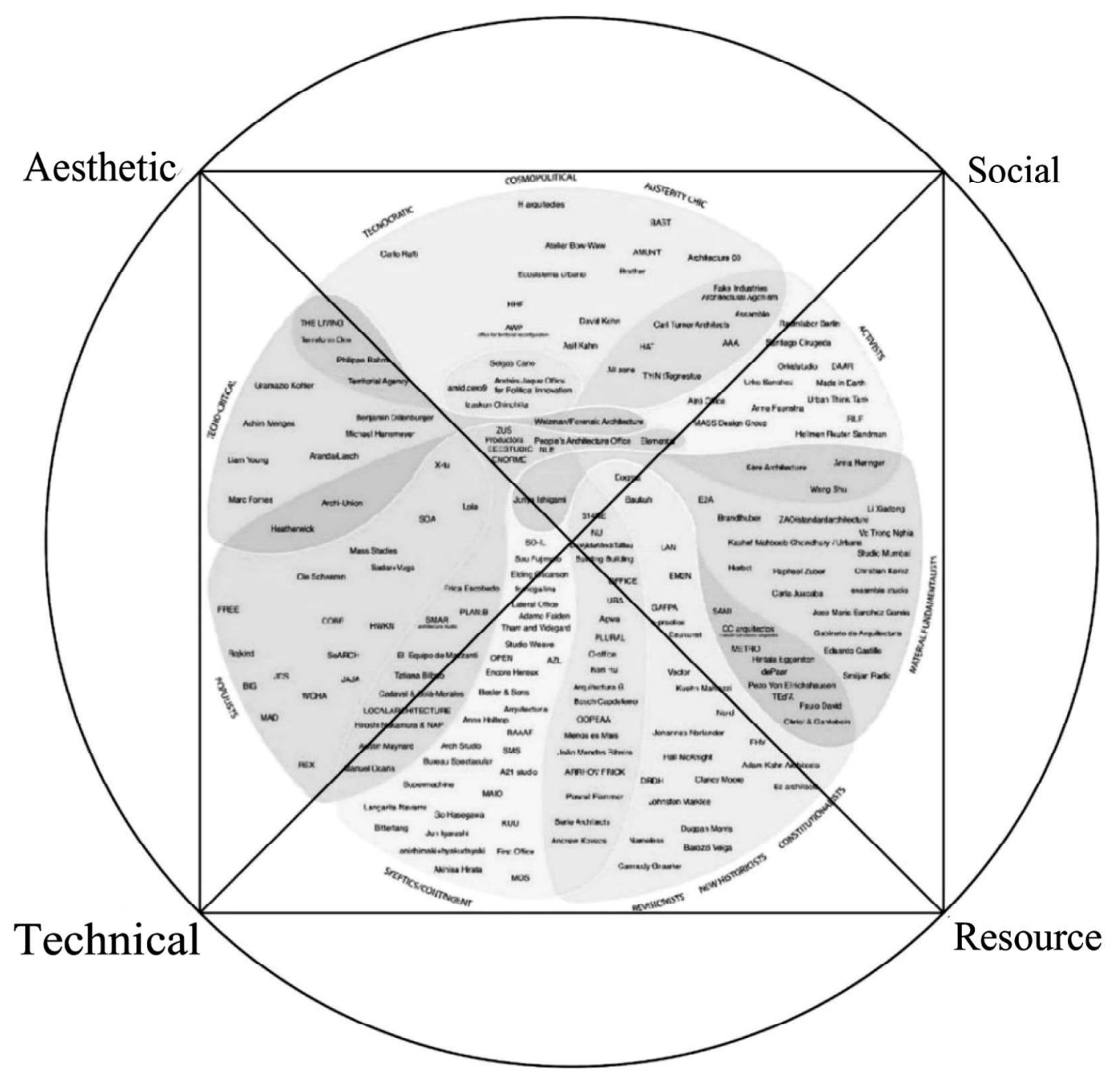

Fig. 3. The Map of modern architecture is supplemented with factors of influence (Yu. Dzhygil, 2017) 
Imagine that a square can rotate (like a rotating arrow in a compass), but the circle of the map remains stationary, like the dial of a compass. Thus, you can put one of the vertices of the square opposite one of the sectors of the circle, which indicate the main seven directions in modern architecture. This will mean that this will be a factor from which we will evaluate the other three in this direction. For example, the aesthetics of activists from the standpoint of unresolved contradictions (antinomies), which are laid down in the Triangle of Social-Technical-Resource problems. Or we can analyze their social orientation through the prism of aesthetic-technical-resource factors. And so on.

The possibility of interactive work with it set by the map authors, namely: update the directions of authors and groups of creative teams; supplement the map content with links to their sites; change the areas of influence of certain areas over time. The next step in the development of the map could be to record such changes in a certain time sequence, which would make it possible to obtain its spatial image similar to the geological core. After all, immersion of the well deep into the rock allows you to extract fluids from the core, which with each meter leaves its unique cross-section pattern, which studies the history and structure of the Earth's crust. Like a geological core, the vertical cylinder of such a compass could periodically accumulate new information and, as it sank, provide information about new works of Architecture, new architectural firms, and changes in style features in the directions of modern architecture. This would allow us to look at the process of changes in modern architecture more clearly. That is, to go to a threedimensional model, as opposed to a sequential linear-plane disclosure of the dynamics of this process, as shown in the diagrams of Ch. Jenks (Jenks, 1985. P. 79; Jencks, 2000).

\section{Conclusions}

The interactive map of Alejandro Zaera-Polo and Guillermo Fernandez Abascal developed Charles Jenks' ideas on the evolution of modern architecture based on trends that emerged in the first 15 years of the 21 st century. The interactive map has become a widely recognized tool for learning and comparing work methods and stylistic features that are manifested in the work of modern architects from around the world. My 5-year experience of working with this map in the framework of the course "Modern Concepts of Architectural Environment Design" allows us to conclude that it is a powerful tool for students to master knowledge in this academic discipline. I believe that this Map in the future can become a prototype for creating a similar diagram, in which it would be possible to see the current state of Ukrainian architecture.

\section{References}

Jencks, Charles. 1985. The language of post-modern architecture / Translated from English by A. V. Riabushin ... Moscow : Stroyizdat.

Cherkes, B. S., Linda, S. M. 2010. Modern architecture. The last third of the XX-early XXI centuries: a textbook. Lviv : Publisher Lviv Polytechnic.

Jencks, Charles. 2000. Jencks' theory of evolution, an overview of 20th Century architecture. [online] The Architectural Review / 12 July 2000 by Charles Jencks archive. Available at: <https://www.architectural-review.com/archive/jencks-theory-ofevolution-an-overview-of-20th-century-architecture> [Accessed date: 26 March 2021].

Arch:speech. News. 2017 a. Modern architecture map: 7 directions, 181 bureaus [online] Arch:speech / 09.06.2017. Available at: $<$ https://archspeech.com/article/karta-sovremennoy-arhitektury-7-napravleniy-181-byuro $>$ [Accessed date: 27 March 2021].

Alejandro Zaera-Polo \& Guillermo Fernandez Abascal. “Architecture's "Political Compass”: A Taxonomy of Emerging Architecture in One Diagram" 16 Dec 2016. ArchDaily. Available at: <https://www.archdaily.com/801641/architectures-politicalcompass-a-taxonomy-of-emerging-architecture-in-one-diagram> [Accessed date: 26 March 2021] ISSN 0719-8884.

Arch:speech. News. 2017 b. An interactive map of the directions of modern architecture has been launched [online] Arch:speech / 05.12.2017. Available at: <http://archspeech.com/article/zapushhena-interaktivnaya-karta-napravleniy-sovremennoyarhitektury> [Accessed date: 26 March 2021]. 


\title{
Юрій Джигіль
}

Канд. арх., доч. кафедри дизайну архітектурного середовища

Інститут архітектури та дизайну

Наиіональний університет “Львівська політехніка", Львів

e-mail: yuriydzhyhil@gmail.com

orcid: 0000-0002-4630-2501

\section{АРХІТЕКТУРНИЙ КОМПАС А. ЗАЕРА-ПОЛО \\ ЯК ІНСТРУМЕНТ ДОСЛІДЖЕННЯ СУЧАСНИХ КОНЦЕПЦІЙ ДИЗАЙНУ АРХІТЕКТУРНОГО СЕРЕДОВИЩА}

\begin{abstract}
Анотація. У статті розглядаються тенденції сучасної архітектури, викладені в дослідженнях архітектурного критика Александро Заера-Поло та його команди. Створений ними інструмент отримав назву "Інтерактивна карта сучасної архітектури”. “Еволючійне дерево” Чарльза Дженкса (схема архітектури XX ст.) справило значний вплив на цей інструмент. Інтерактивна карта стала загальновизнаним інструментом для вивчення та порівняння методів роботи та стилістичних особливостей, щзо виявляються в роботі сучасних архітекторів з усього світу. Функиіональність карти Заера-Поло протягом п'яти років вивчалася автором иієї статті під час навчання майбутніх архітекторів на кафедрі проектування архітектурного середовища Національного університету “Львівська політехніка”. Ці експертизи дозволили сформулювати низку пропозицій щодо вдосконалення обох - структури иієї карти та методології ï створення. Зазначається, щзо інтерактивна карта є потужним інструментом для здобуття студентами знань 3 дисиипліни "Сучасні концепиії проектування архітектурного середовища". Передбачається, щуо ия карта може стати прототипом діаграми "Сучасний стан сучасної украӥнської архітектури” у майбутньому.
\end{abstract}

Ключові слова: сучасна архітектура, інтерактивна карта, політичний компас. 